E-

\title{
ANALÝZA ERP SYSTÉMOV NA SLOVENSKOM TRHU
}

\author{
Martina Kováčiková* Gabriela Surovčáková*
}

\section{Úvod}

Podnikový informačný systém predstavuje prostriedok pre efektívne fungovanie podnikových procesov. Funkcie IS sú preto odvodené od podnikových ciel'ov a potrieb podnikových procesov.

Manažment podniku a koncový užívatel' má vzhl'adom na informačný systém určité očakávania:

- manažment podniku - očakáva podporu podnikových ciel’ov, získanie konkurenčnej výhody, pravdivý a včasný informačný obraz reality $\mathrm{v}$ rôznych vecných a časových súvislostiach, informácie podporujúce dlhodobú stratégiu firmy, analytické informácie,

- koncový užívatel' - očakáva podporu riešenia potrieb vyplývajúcich z funkčného miesta, podrobné a aktuálne informácie, riešenie každodenných podnikových aktivít, intuitívne a užívatel'sky prívetivé rozhranie.

Informačný systém kategórie ERP je účinný nástroj, ktorý je schopný pokryt' plánovanie a riadenie hlavných interných podnikových procesov (zdrojov a ich transformáciu na výstupy), a to na všetkých úrovniach riadenia, od operatívneho až po strategické. Predstavuje väčšinou jadro aplikačnej časti informačných systémov a pokrýva mnoho funkcií a kl'účových procesov. Klúčovými procesmi sú myslené hlavné hodnototvorné procesy daného podniku výroba, logistika, personalistika a ekonomika. [1] Z hl'adiska klasifikácie ERP systémov podl'a odborového a funkčného zamerania, je možné sledovat' tri základné kategórie [2]:

- ERP systém All in One - majú schopnost' pokryt' všetky kl’účové interné podnikové procesy. Výhodou je vysoká úroveň integrácie, dostačujúca väčšine spoločností. Nevýhodou je nižšia detailná funkcionalita, nákladná customizácia,

- Best-of-Breed - ich základnou charakteristikou je orientácia na špecifické odbory alebo procesy, nemusí pokrývat' všetky procesy. Výhodou je špičková detailná funkcionalita alebo špecifické odborové riešenia, nevýhodou môže byt' st'ažená koordinácia procesov, nutnost’ riešenia viacerých IT projektov,

\footnotetext{
* Ing. Martina Kováčiková, PhD., Žilinská univerzita v Žiline, Fakulta Prevádzky a ekonomiky dopravy a spojov, Katedra spojov, Univerzitná 1, 0126 Žilina,

tel.: +421415133106, fax: +421415655 615

e-mail: martina.kovacikova@fpedas.unmiza.sk

* Bc. Gabriela Surovčáková, študent, Žilinská univerzita v Žiline, Univerzitná 1, 0126 Žilina,
} 
- Light ERP - sa vyznačujú odl'ahčenou verziou štandardného ERP riešenia, zameranou na trh malých a stredne vel'kých firiem. Ich výhodou býva nižšia cena a rýchla implementácia, no nevýhodou môže byt' obmedzená funkcionalita, počet používatel'ov, customizácia a pod.

\section{ERP systémy na svetovom trhu}

Svetový trh je charakteristický výraznou koncentráciu síl dodávatel'ov ERP systémov, aby zabezpečili dlhodobú globálnu podporu a rozvoj svojich produktov. Tí silnejší skupujú konkurenčné riešenia, know-how, časti produktových portfólií alebo celú spoločnost'. Dochádza $\mathrm{k}$ akvizíciám a konsolidáciám, k d’alšiemu rozvoju ERP systémov, zvyšuje sa podiel neúspešných projektov ERP. Akvizície realizované za účelom získania nových zákazníkov a podielu na trhu môžu byt' problematické hlavne $\mathrm{v}$ prípade, ak ide o tzv. nepriatel'ské akvizície. Medzi hlavné riziká pre zákazníkov odkúpených spoločností patrí neistota udržania podpory implementovaných systémov, tlak vyvíjaný novým dodávatel'om, ktorý sa snaží presvedčit' zákazníkov k prechodu na iný informačný systém. Akvizícia má pre zákazníka význam len v prípade, že prináša know-how alebo obohacuje produktové portfólio. [2] [3]

V období globálnej ekonomickej krízy sa snažia podniky využívat' svoje finančné prostriedky viac zodpovedne v každej oblasti. Oblast' informačných systémov nie je výnimkou. Čoraz nižšie rozpočty a málo času na kvalitné strategické rozhodnutia však vedú k výberu ERP podl'a ceny. Takéto systémy napokon nedostatočne spĺn̆ajú požiadavky a potreby podnikov a tým dochádza $\mathrm{k}$ premrhaniu investícií. [4]

V súčasnosti na trhu ERP dominujú Severná Amerika a Európa. Za rozvíjajúce sa oblasti môžeme označit’ Áziu, oblast' Tichomoria a Latinskú Ameriku, ktoré zaznamenávajú v tejto oblasti výrazný rast. V percentuálnom zastúpení výšky investícií do ERP systémov vedie Severná Amerika, ktorej podiel na ročných investíciách do ERP systémov predstavuje $46 \%$, nasledujú podniky pôsobiace v Európe s $39 \%$ podielom. Zvyšný podiel vo výške $15 \%$ dosahujú podniky pôsobiace v Ázii, Latinskej Amerike a ostaných častiach sveta. [5]

Na svetovom trhu ERP dominujú dvaja významní dodávatelia ERP systémov, SAP a Oracle. Obaja medzi sebou súperia už desiatky rokov, sú schopní prispôsobovat' sa meniacim sa nárokom svojich klientov a zmenám v ekonomickom prostredí. Ďalším významným lídrom na trhu ERP je Microsoft, no nie na rovnakej úrovni ako SAP a Oracle. Spoločne však tvoria silný celok, nazývaný Tier I. [6] Svetový trh ERP systémov môžeme podl'a nezávislej poradenskej spoločnosti v oblasti ERP, Panorama Consluting Solutions, členit' do troch kategórií, označovaných ako Tier:

- Tier I - SAP, Oracle Corporation, Microsoft, tieto systémy využívajú hlavne vel'ké podniky so zložitými operačnými štruktúrami. Vyznačujú sa širokým a detailným pokrytím podnikových procesov

- Tier II - Aptean CDC Software, Epicor Software Corporation, Consona Corporation, Deltek Systems, Exact Software, IFS, Infor Global Solutions, Lawson Software, Sage North America, SYSPRO, Exact Software a iní, dodávatelia týchto systémom sú preferovaní najmä u stredne vel'kých podnikov s menej zložitými operačnými štruktúrami,

- Tier III - ABAS Software, American Software, Business Computer Resources, Micron Software Systems, Open Systems, Softrader Limited, Bluebee Software, Ascentis Corporation, eSoftware Professionals a iní, túto kategóriu využívajú najmä malé a stredne vel'ké podniky s jednoduchými operačnými štruktúrami. 
Nezávislá poradenská spoločnost’ Panorama Consulting Solutions vypracovala analýzu obsahujúcu odpovede od viac ako 2000 respondentov zo 61 krajín sveta, ktorí využívali ERP systémy od dodávatel'ov SAP, Oracle alebo Microsoft. Zber sa realizoval od februára 2006 do mája 2012. Podl'a výsledkov tejto analýzy dosahuje najvyšší percentuálny podiel na trhu ERP systémov, už tradične, SAP s $22 \%$. SAP si prvenstvo na svetovom trhu udržuje už niekol'ko rokov. Jeho trhový podiel predstavuje $\mathrm{v}$ súčasnosti viac ako pätinu $\mathrm{z}$ celkového podielu na trhu ERP. Druhé miesto obsadil Oracle s $15 \%$ a tretie miesto Microsoft s trhovým podielom $10 \%$. Pri súčte jednotlivých hodnôt dosahuje skupina Tier I až 47\%. Celkový trhový podiel Tier II, vrátane systémov od dodávatel'ov Infor a Epicor predstavuje len 16\%. ERP systémy skupiny Tier III zaberajú zostávajúcich 37\%. [6]

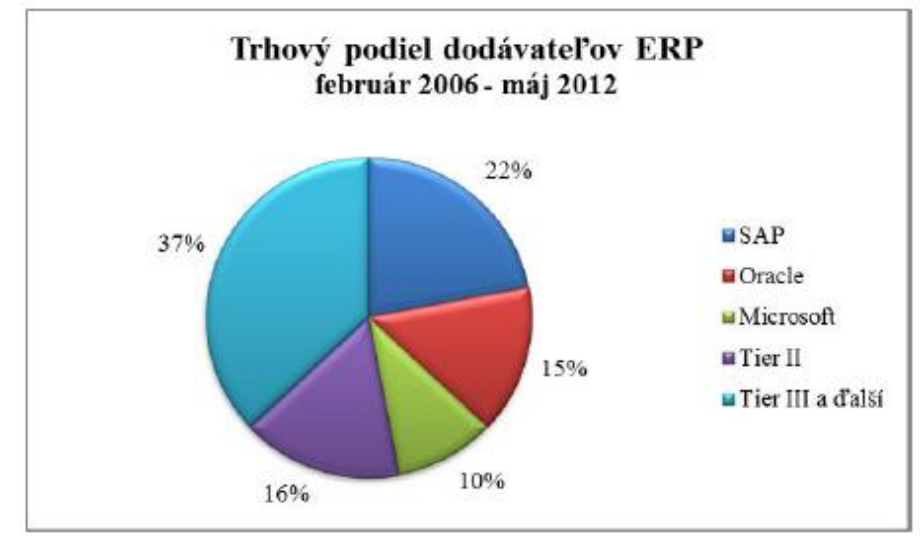

Obrázok 1. Trhový podiel dodávatel’ov ERP február 2006 - máj 2012 (Zdroj: Clash of the titans. [online]. [cit. 2013-02-20]. Dostupné na internete: <http://panorama-consulting.com/Documents/Clash-of-the-Titans2012.pdf $>$. Spracovanie: Surovčáková Gabriela: Podnikové informačné systémy v Slovenskej republike, bakalárska práca, Žilinská univerzita v Žiline, 2013)

\section{ERP systémy na slovenskom trhu}

Vstup Slovenska do Európskej únie priniesol nielen nárast zahraničného obchodu, ale aj konkurencie. Práca manažmentu s aktuálnymi informáciami o stave podniku, požiadavkách zákazníkov či potrebách partnerov sa považuje za nevyhnutnost'. Vzrástli nároky na kvalitu riadenia, efektivitu využívania zdrojov, zvýšili sa požiadavky na flexibilný prístup k potrebám zákazníkov a prispôsobenie sa novým štandardom. S rastom slovenskej ekonomiky rastú aj požiadavky podnikov na podnikové informačné systémy. Rastie dopyt po komplexných riešeniach, ktoré zabezpečia nielen základné funkcie, ale aj výstupy a riadenie celého podnikového procesu. Významnou črtou slovenského trhu ERP je neustále sa zvyšujúca konkurencia, ktorá má za následok znižovanie cien ERP. Kvalitné ERP systémy sa stávajú dostupnými aj pre malé a stredné podniky, ktoré cítia vel'kú potrebu zefektívňovat' svoje vnútropodnikové procesy, avšak si nemôžu dovolit' vysoké investície na implementáciu vel'kých informačných systémov a nemajú na implementáciu zriadené IT oddelenie. Zvýšený dopyt po integrovaných a štandardných riešeniach začal oslabovat' postavenie lokálnych dodávatel'ov ERP systémov. $Z$ tohto dôvodu začalo dochádzat' $\mathrm{k}$ zániku menších výrobcov a posilneniu postavenia súčasných producentov. Konkurenčný boj vel'kých dodávatel'ov ERP nie je typický len pre slovenský trh, ale aj pre strednú a východnú Európu. [7]

V súčasnej dobe sa nepovažuje cena za hlavný faktor, ktorý ovplyvňuje výber ERP. Vel'ký dôraz sa kladie na kvalitu a spol'ahlivost'. Podniky začínajú uprednostňovat' dodávatel'ov, ktorí ponúkajú aj doplnkové služby, ako napr. školenia, inštalácie, servisné zásahy, poradenstvo, individuálne programové úpravy.

Redakcia magazínu Infoware už niekol'ko rokov realizuje prieskumy predaja podnikových informačných systémov ERP na slovenskom trhu. Pri realizácií prieskumu 
bývajú oslovené obchodné zastúpenia zahraničných podnikov pôsobiacich na Slovensku, predajcovia a implementátori ich produktov, systémoví integrátori či lokálni producenti ekonomických informačných systémov. Do prieskumov sú zahrnuté riešenia pre menších zákazníkov a komplexné riešenia pre stredných a vel'kých zákazníkov, ktoré poskytujú služby pre všetky kl'účové vnútropodnikové procesy. Väčšina dodávatel'ov sa orientuje na vybraný segment trhu z hl'adiska vel'kosti zákazníka. Iba niekol'kí poskytujú ERP systémy pre segment vel'kých podnikov a súčasne iný produkt pre menšie a stredné podniky. V štúdií niekol'ko dodávatel'ov neuviedlo kompletné údaje, napr. údaje $\mathrm{v}$ absolútnom vyjadrení hlavne pre neochotu poskytovat' takýto typ údajov, pretože ich považujú za príliš citlivé. Niektoré zahraničné podniky, ktoré sú kótované na burze, nemajú dovolené publikovat' lokálne hospodárske výsledky, takže údaje o ich výsledkoch sú poskladané z podkladov ich partnerov ako kvalifikovaný odhad magazínu Infoware. Iné podniky, ktoré si nevedú presnú evidenciu informácií, napr. o charaktere zákazníkov použili taktiež kvalifikovaný odhad. [8] [9]

V roku 2010 sa prieskumu zúčastnilo 25 dodávatel’ov s 37 produktmi, v roku 2011 bolo dodávatel'ov 26 a ponúkali 39 produktov. Produkty sú zamerané od jednoúčelových systémov na vedenie účtovníctva a mzdy pre menšie podniky až po komplexné ekonomické informačné systémy pre vel'kých zákazníkov.

Podla údajov slovenských výrobcov a dodávatel'ov lokálnych podnikových informačných systémov, ako aj slovenských zastúpení zahraničných dodávatel'ov vel'kých ERP systémov boli celkové tržby z predaja ERP v roku 2010 na úrovni 74464081 EUR a v roku 2011 na úrovni 71948856 EUR. Z uvedeného vyplýva, že v roku 2011 boli celkové tržby za produkty ERP oproti roku 2010 nižšie o 2515225 EUR. Na slovenskom trhu ERP systémov v roku 2011 výrazne dominoval dodávatel' SAP Slovensko (umiestnenie na prvom mieste aj v roku 2010) s celkovými tržbami vo výške 35364170 EUR, čo predstavuje 49,2\% podiel na trhu. Jeho tržby vzrástli oproti roku 2010 o 0,9\%. Druhé miesto patrí dodávatel'ovi SOFTIP (umiestnenie na druhom mieste aj v roku 2010) s tržbami vo výške 8927000 EUR, teda s 12,4\% podielom na trhu i ked' oproti roku 2010 jeho tržby klesli o výrazných 22,6\%. $\mathrm{Na}$ tret'om mieste sa umiestnil Asseco Solutions (nahradil KROS z roku 2010) s celkovými tržbami za ERP vo výške 6861000 EUR. Jeho podiel na trhu ERP za rok 2011 dosiahol $9,5 \%$.

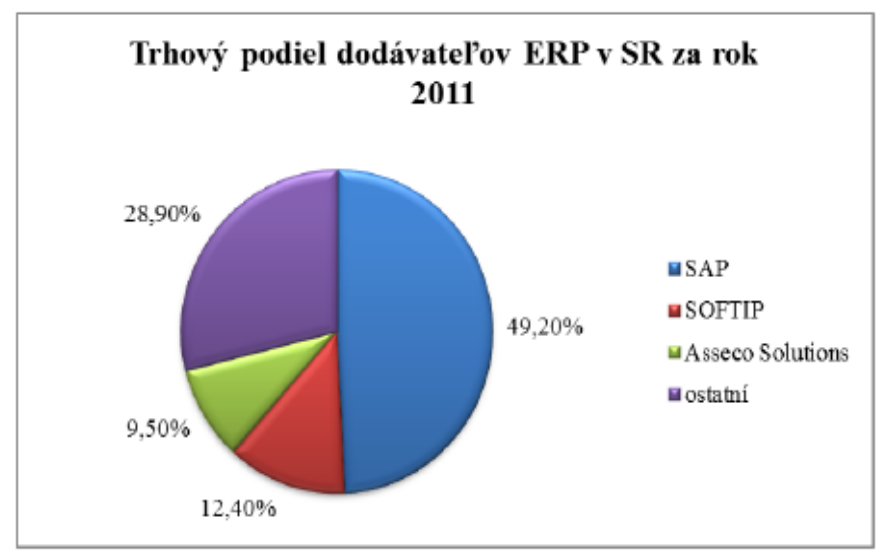

Obrázok 2. Trhový podiel dodávatel’ov ERP v SR za rok 2011 (Zdroj: Surovčáková Gabriela: Podnikové informačné systémy v Slovenskej republike, bakalárska práca, Žilinská univerzita v Žiline, 2013)

V roku 2010 evidovali dodávatelia spoločne 74096 zákazníkov. V roku 2011 sa ich počet zvýšil na 80953 . Najvyšší počet zákazníkov v oboch porovnávaných rokoch dosiahol dodávatel' KROS s produktmi Alfa, Olymp a Omega. Za ním nasleduje dodávatel' Cígler 
Software s produktom Money. Vysoký počet zákazníkov vyplýva z ich zamerania prevažne na malé podniky do 10 zamestnancov. [8] [9]

\section{Analýza využitia ERP systémov na Slovensku}

V súvislosti so sledovanou problematikou bol realizovaný prieskum, zameraný na využitie a podporu ERP systémov na Slovensku [10] a to v rámci vypracovania bakalárskej práce. Čiastkové ciele podporujúce orientáciu prieskumu boli zamerané na zistenia:

- do akej miery využívajú podniky v Slovenskej republike informačné systémy.

- ktoré funkčné oblasti podporujú využívané informačné systémy.

- aké sú vízie podnikov do budúcna z hl'adiska implementácie informačného systému a investícií do informačného systému.

Prieskum bol realizovaný v období od 15. marca 2013 do 10. apríla 2013. Za metódu zberu údajov bolo zvolené dopytovanie prostredníctvom elektronického dotazníka. Metóda bola zvolená z dôvodov: nízkej finančnej náročnosti, rýchlosti, jednoduchému spracovaniu elektronických údajov a možnosti zasiahnut' vel'ký počet podnikov z rôznych regiónov Slovenska.

Dotazník celkovo vyplnilo 174 podnikov. Z celkového počtu bolo 39 živnostníkov $(22,41 \%)$, 101 spoločností s ručením obmedzeným $(58,05 \%), 29$ akciových spoločností $(16,67 \%)$ a 5 podnikov s inou právnou formou $(2,87 \%)$. Počet podnikov v miestnou pôsobnost'ou, teda pôsobnost'ou v rámci obce, mesta bolo $38(21,84 \%)$, podnikov s regionálnou pôsobnost'ou, teda pôsobnost'ou v rámci kraja bolo $31(17,82 \%)$. Do prieskumu sa zapojilo 48 podnikov s národnou pôsobnost'ou $(27,59 \%)$ a 57 podnikov s medzinárodnou pôsobnost'ou $(32,75 \%)$. Z hladiska vel'kosti podnikov sa dotazníkového prieskumu zúčastnilo 104 mikropodnikov, 45 malých podnikov, 14 stredných podnikov a 11 vel'kých podnikov. (Nasledovné zistenia sú z dôvodu prehl'adnosti zaokrúhl'ované.)

Prvá meritórna otázka dotazníka bola selekčná, zameraná na aktuálne využívanie informačných systémov v podnikoch. Vyhodnotením tejto otázky bolo zistené, že len $\mathbf{5 8} \%$ z podnikov zúčastniacich sa prieskumu využíva pri svojej podnikatel'skej činnosti informačné systémy. Len $7,5 \%$ podnikov plánuje do budúcna implementovat' podnikový informačný systém a 34,5\% podnikov neuvažuje o implementácii podnikových informačných systémov. Následne sa dotazník zameriaval na skúmanie využitia informačných systémov v závislosti od vel'kosti podniku. Prieskumom bolo zistené, že s vel'kost'ou podniku sa zvyšuje percento využívania informačných systémov v podnikoch.

Z hl'adiska dodávatel'a informačných systémov bolo prieskumom zaznamenané zistenie, že až u 94\% vyhodnotených odpovedí ide o dodávatel'a externého, v $6 \%$ išlo o vlastný vývoj - využitie vlastného informačného systému. Možnost' kombinácie externého dodávatel'a $\mathrm{s}$ vlastným systémom nebola $\mathrm{v}$ ani jednom prípade potvrdená. $\mathrm{Z}$ hl'adiska konkrétnych dodávatel'ov informačných systémov sa na prvých troch miestach umiestnili: KROS, SOFTIP a Cigler Software. Z hl'adiska špecializácie informačného systému 29\% opýtaných využíva špecializovaný informačný systém a $71 \%$ podnikov využíva ERP systém.

Z hl'adiska oblastí, ktoré využívaný informačný systém podporuje bolo zistené, že podniky najviac využívajú informačné systémy v rámci oblastí: účtovníctvo, fakturácia , pokladňa, mzdy a personalistika, zásobovanie a logistika, výrobný proces, zriedka pre plánovanie projektov, skladové hospodárstvo a správu nehnutel'ností.

V súvislosti so sledovaním prínosu z implementácie informačného systému podniky odpovedali nasledovne: zlepšenie dostupnosti informácií $67 \%$, zlepšenie nadväznosti procesov $23 \%$, zvýšenie produktivity práce $10 \%$ odpovedí.

V rámci prieskumu bol sledovaný aj zámer podnikov do budúcnosti v súvislosti s plánovaním investícií do informačného systému. Zo získaných odpovedí je možné 
konštatovat', že $43,5 \%$ podnikov $v$ budúcnosti plánuje investície do informačných systémov, $22 \%$ podnikov neplánuje investovat' do informačného systému a 34,5\% $\mathrm{z}$ dopytovaných podnikov sa $\mathrm{k}$ tejto otázke nevedelo presne vyjadrit'.

Zo získaných odpovedí bolo prieskumom zistené, že len necelých $60 \%$ zo zúčastnených podnikov využíva informačný systém pri svojej podnikatel'skej činnosti. $\mathrm{Z}$ podnikov, ktoré tieto systémy využívajú je viac ako $60 \%$ systémov kategórie ERP. $\mathrm{z}$ hl'adiska trendov rozvoja informačných systémov $\mathrm{v}$ podnikoch, sa prieskumom zistilo, že len menej ako 50\% podnikov plánuje do budúcna investície do informačných systémov.

\section{Záver}

Podnikové informačné systémy sú významným nástrojom pre plánovanie a riadenie podnikových zdrojov, ktoré poskytujú potrebné informácie a podporuje hlavné podnikové procesy na všetkých úrovniach. V súvislosti so sledovanou problematikou je možné konštatovat', že podniky na Slovensku vo väčšej miere využívajú komplexné podnikové informačné systémy ERP (oproti špecializovaným informačným systémom), ktoré podporujú viacero funkčných oblastí súčasne. V oblasti d’alších investícií do informačných systémov nájdeme množstvo podnikov, ktoré tento krok plánujú uskutočnit'. Z hl'adiska využitia už implementovaných informačných systémov je možné konštatovat', že podniky v prostredí informačných systémov pracujú intenzívne a vysoké percento z nich je s využívaným informačným systémom spokojné.

\section{Literatúra}

[1] TVRDÍKOVÁ, M. Aplikace moderních informačních technológií v řizení firmy. Praha: Grada Publishing, 2008. 176. ISBN 978-80-247-2728-8

[2] SODOMKA, P. Informační systém v podnikové praxi. Brno: Computer Press. 2006. 135 s. ISBN 80-251-1200-4

[3] RYBA, A. ERP systémy v roce 2012: Vybírejte s rozmyslem. In ICT manažer. [online]. 2011 . Dostupné na internete: <http://www.ictmanazer.cz/2011/12/erp-systemy-v-roce2012-vybirejte-s-rozmyslem/>. ISSN 1805-5486.

[4] Global ERP Software Market to Reach US\$67.8 Billion by 2015, According to New Report by Global Industry Analysts, Inc.. [online]. [2013-02-27]. Dostupné na internete:<http://www.prweb.com/releases/ERP_software/EAM_software/prweb3772994 .htm>.

[5] KÁDÁROVÁ, J. Analýza trhu ERP systémov. In TRANSFER INOVÁCIÍ. [online]. 2011 [cit. 2013-02-20]. Dostupné na internete: <http://www.sjf.tuke.sk/transferinovacii/pages/archiv/transfer/21-2011/pdf/271-274.pdf>. ISSN 1337-7094. 52

[6] PANORAMA CONSULTING SOLUTIONS. Clash of the Titans. 2012. [online]. [cit. 2013-02-20]. Dostupné na internete: <http://panorama-consulting.com/wpcontent/uploads/2009/10/Clash-of-the-Titans-2012.pdf>.

[7] DROBNÝ, M. Slovenský trh podnikových informačných systémov. In INFOWARE [online]. 2007, no. 5 [cit. 2013-02-24]. Dostupné na internete: <http://www.emel.sk/DownloadDocuments/napisali_o_nas_erp_systemy.pdf >.

[8] IT ročenka 2012. 2012. [online]. Bratislava : Digital Visions, august 2012. [cit. 2013-0220]. Dostupné na internete: <http://static.itnews.sk/a542/file/item/sk/0000/it_rocenka_12.ldYc.pdf>. 
[9] IT ročenka 2011. 2011. [online]. Bratislava : Digital Visions, august 2011. [cit. 2013-0220]. <http://static.itnews.sk/a542/file/item/sk/0000/itr_2011_kompleti.nVWa.pdf >.

[10]SUROVČÁKOVÁ G.: Podnikové informačné systémy v Slovenskej republike, bakalárska práca, Žilinská univerzita v Žiline 2012, školitel’: Kováčiková Martina

[11]Hnatova, Z., Kremenova, I., Fabus, J.. Some aspects of managing information technology services [Niektoré aspekty riadenia služieb informačných technológií] / In: IETC 2010 [elektronický zdroj] : 10th international educational technology conference : April 26-28, 2010 Istanbul, Turkey : proceedings book. - [S.1.]: IETC, 2010. - S. 1345-1347.

\section{Grantová podpora}

VEGA 1/0199/11 Výskum interoperability metód riadenia so strategickým zámerom organizácie

Inštitucionálny výskum 4 /KS/2013 Uplatnenie procesného riadenia v podniku služieb 